\title{
TRANSLATION SHIFTS IN INDONESIAN VERSION OF SHELDON'S WINDMILLS OF THE GODS
}

\author{
Ira Miranti \\ ade_miranti@yahoo.com \\ Universitas PGRI Indraprasta Jakarta
}

\begin{abstract}
This article discusses one of the linguistic challenges discovered in a translation product, namely shifts. The shifts in translation product are inevitable due to numbers of factors, such as cultural differences and unique language systems. The approach used to describe the findings is descriptive-qualitative by having textual data from the source language in English and target language in Indonesian. Having these comparisons will assist to focusing on the analysis of shifts happened in the translation. The data source is one of Sidney Sheldon's famous novel Windmills of the Gods and its translation in Indonesian language Kincir Angin Para Dewa. There are 112 shifts found in the Indonesian translation, yet this article focuses on ten most representative translation shifts based on Catford's (1974) translation shifts' concepts, that is shift of level and shift of category. In this case, the article will take more portion to describe the clause shifts in particular.
\end{abstract}

Keywords: translation shifts, clause, complex sentences, English-Indonesian

\section{INTRODUCTION}

A translation is considered as the best product if the one which: (1) uses the normal language forms of the receptor language; (2) communicates, as much as possible, to the receptor language the same meaning that was understood by the speaker of the source language; and (3) maintain the dynamics of the original source language text (Larson, 1998, 6). When a certain discourse is translated into another language, all elements which constitute the discourse should be preserved. In the practice of translation, however, a translator encounters a problem that is how he or she can be able to express the meaning of source language naturally, clearly, and accurately in the receptor language. In this case, shifts will be unavoidable.

This research is carried out because the structures of English complex sentences are different with those of the Indonesian. Sometimes, one type of clause, which is a part of a complex sentence, is translated into another clause or it is translated into the same kind of clause but with a different subordinate conjunction. This transition happens due to several natures, i.e. English and Indonesian came from a different language family resulting different language systems to each of these languages. English is an IndoEuropean language family (Bloomfield, 1996, 57-59), while Indonesian, if we have a look at its historical side, is a language derived from the Malayan language which then has been enriched by foreign and regional languages and eventually not longer the same as the Malayan language (Badudu 1992, 7).

A relevant research was carried out by Hellystia (2013). The similarity with the article is that both topics discuss the shift at a grammatical level. The difference is that shediscussed the equivalence in addition to shifts, in the compound and complex sentences. Language direction is from Indonesian into English, while this article analyses translation shifts from English into Indonesian. Moreover, this article also concerns with shifts simply within the clause in complex sentences from 
English into Indonesian.In line with these limitations, the research conducted should cover all clauses in complex sentences for example if there is a complex sentence with a sub-clause which has a sub-clause, all the clauses in the independent clause as well as in the subclause should be analyzed. However, due to the limited time allotted to finish this research, the researcher only analyzes the clauses in the first dependent clause, not in the subclause dependent clauses.This research aims at finding out how English clauses are translated into Indonesian and discovering the kinds of shifts that occur.

Although there have been many studies conducted on translation shifts from English into Indonesia, which also discussed shifts in complex sentences from English into Indonesian-it is stillnecessary to carry out this research as to enrich data on evidence of language shifts occurred in literary translation context. Therefore, this study will be able to give a descriptionon language shifts took place in the translation of English clauses into Indonesian; this evidence supports the body of knowledge in translation studies in further research.

\section{LITERARY REVIEW}

Naturally, translating from one language into another language involves difficulties, both linguistic and metalinguistic. In the translation process, certain mismatches or shifts may often be unavoidable (thus obligatory) because of the differences in linguistics, stylistic, and dissimilarities between cultures of the speakers. In linguistics, the problem deals with language structure. Every language has its own linguistic system, and each language has its own division of the lexicon into classes such as nouns, verbs, adjectives. Different languages will have different classes and subclasses. It will not always be possible to translate a source language noun with a noun in the receptor language (Larson, 1998, 18). Then, the translator should be able to find the closest natural equivalence of the source language in the target one, for example, an English expression such as 'Is this where you live?' can be translated into an Indonesian expression Kau tinggal di sini? If we look at the Indonesian translation, we can find a shift from a noun clause into a sentence. The complex sentence 'Is this where you live?' contains a noun clause 'where you live?'. The translator did not retain the original structure of the source language, so s/he changed it into a sentence because if $\mathrm{s} / \mathrm{he}$ retained its structure (e.g. Apa di sini di mana kamutinggal?), the translation would not sound natural, although both the source and target languages are in the form of interrogative. The shift is performed to find a natural form in the target language and an equivalent meaning with the source language.

Newmark $(1988,85)$ defines a shift or transposition as a translation procedure involving a change in grammar from SL into TL. In addition to that, shift on a microstructural level covers words, clauses, and sentences (Gentzler 1993, 137). Another wellknown and best representative model on translation shift is presented in two kinds of shift, i.e. shift of level and shift of category.

The level shift is "something which is expressed by thegrammar in one language and lexis in another" (Munday 2000, 60). This kind of shift consists of atransition from clause to word and clause into phrase.

Category shift is divided into four types: structural shift, class shift, unit shift or rank shift, and intra-system shift (Catford 1974, 77; Munday 2000, 61). Structural shifts may occur in all language units: the unit of phrases, clauses, and sentences. According to Longman Dictionary of Language Teaching and Applied Linguistic (2010), class (in linguistic) means a group of 
items which has something in common, for example, in English words can be grouped or classified into word class (noun, adjective) according to how they combine with other words to form phrases and sentence.This definition is in line with Kridalaksana (2009, 104) who states that the term 'class' here means a group of words that has similar formal attitude, classification on the noun, adjective, and others.

The structural shift occurs if the elements in the TL are different from the SL or if the element orders in the TL are different with the SL, for example:

\section{SL : Although he had had ample} opportunity to cheat on his wife, he had never given another woman a thought.

TL : Ia tak pernah memberi tempat wanita lain dalam pikirannya, meski ia punya kesempatan yang luas untuk memperdayakan istrinya.

The English complex sentence in SL consists of one main clause 'he had never given another woman a thought' and one sub-clause 'although he had had ample opportunity to cheat on his wife'. In the English complex sentence, the main clause is placed after the subclause while in its translation the subclause is put after the main clause.

There is a shift in the position of the main and sub-clause. Class shifts comprise shifts from one part of speech to another, for example:

SL : It smells rather good.

TL : Baunya lumayan sedap.

In SL, the verb 'smells' is a form of a verb but it is translated into Indonesian noun baunya. Therefore, a class shift occurs from verb to noun in the translation.

Catford $(1974,79)$ states that unit shift or rank shift is a shift where the translation equivalent in $\mathrm{TL}$ is at a different rank to the SL. 'Rank' here refers to the hierarchical linguistic units of the sentence, clause, group, word, and morpheme. Here is an example of a unit shift:

SL: Would you say that you know Mrs. Ashley well?

TL : Apakah Anda telah mengenalnya dengan baik?

In the English language, a complex sentence shown in SL consists of the main clause 'would you say' and a subclause 'that you know Mrs. Ashley well'. The main clause is the main clause of a noun clause which translated into a question word apakah. The unit shift happens from clause to word. Intra-system shifts mean a departure from formal correspondence in which (a term operating in) one system in the SL has its translation equivalent (a term operating in) a different-no-corresponding-system in the TL.

\section{METHODS}

Dealing with research, Nunan $(1992,3)$ states that:

Research is a systematic process of inquiry consisting of three elements or components: 1) a question, problem, or hypothesis, 2) data, 3) analysis and interpretation of data. Any activity which lacks one of these elements (for example, data) will be classified as something other than research.

Research is a systematic investigation to find the answer to a problem. Research in professional social science areas, like studies in another subject, has generally followed the traditional objective scientific method (Burns 2000, 3). While Hornby (1989, 1073)states that "research is a careful study or investigation, especially to discover new facts or information." It can be concluded that the research is an investigation in many fields of study to find the answer to a problem in a systematic process consisting elements which must be available.

This research uses a qualitative approach which is emphasized by the following item, such a grounded, discovery-oriented, exploratory, expan- 
sionist, descriptive, and inductive (Nunan, 1992, 3). Besides, this research uses also the quantitative approach because the data being analyzed is taken from somebody's translation. This means that the analysis is oriented on the outcome of a person's work of which the implication is that this research is an outcome-oriented: reliable: 'hard' and replicable data. Assuming a stable reality (Nunan 1992, 3) is one of the characteristics of quantitative research.

A sub-category of this descriptive research is documentary analysis. What is meant by a document "...paper, form, book, etc. giving information about something, evidence, or proofof something" (Hornby 1989, 386). Halliday (1994, xiv) defines text as any authentic stretch of written or spoken language. A text is a semantic unit, not a grammatical one. The words in this text are being analyzed. That is why it is a documentary analysis focuses on text analysis. Both novels, hence, was treated as a document that provided the writer information as the source language and target language evidence. The evidence were texts supplied for documentary analysis. Thus, this research is a documentary analysis focusing on analyzing text from novels. The technique employed was a descriptive-analytical. An English novel Windmills of the Gods (1987) originally published in English language and its Indonesian translation Kincir Angin Para Dewa (2003) which is translated by Irina M, Susetyo, and Widya Kirana were the source of the data for this analysis.

The data collected from this research are qualitative data which means the data were recorded in a nonnumerical form such as the data identified from the books under study (Nunan 1992, 231). In collecting the data, the researcher employed these following procedures:first, identifying complex sentences which had clauses in the source language text; second, determining the translation of the complex sentence mentioned at the first step of data collection procedure. Next procedure was creating a table to identify data of the two languages - the source language (SL) and target language (TL). The data were grouped into two parts, namely English and Indonesian. The collected data was then categorized and put in each relevant classification on Catford's translation shift model. The final activity, called synthesizing, is done after all analyzing steps have been taken. In this research, the researcher synthesized the result of the analysis by applying the related translation theories.

\section{FINDINGS AND DISCUSSIONS}

After analyzing the data of this research, i.e. English clauses in complex sentences into Indonesian in the English novel entitled Windmills of the Gods and its Indonesian translation Kincir Angin Para Dewa, there were 245 data of complex sentences found in the novel. Due to the limitation of space, the numbers of the shifts observedw ere narrowed down into 112 data. However, the number were still considered to be selected into eight most representative data suitable for the purpose of this article. Ten most representative data were categorized into two Catford's (1997) main levels of shift previously mentioned in the earlier section.

\section{Shift of Level}

\section{Shift from clause into word}

Since a word is the smallest unit of a sentence, it is essential in building up a sentence. According to Chaer (2006, 86) every word has a concept of meaning and a role in a language application. Its concept and role depend on the type or class of the word. Word is the smallest unit of a sentence which is able to stand alone and has its own meaning.

In addition to that a unit which is constructed from a combination of letters and/or morphemes can be 
considered as word when it already has a meaning (Finoza 2006, 76).

A word can stand alone and has a concept of meaning and role in a language. The idea of meaning and role depends on the kind of the word. For example, the word sepeda (bike), ambil (take), dingin (cold). These three words are mentioned to be words because they have to mean and it is evident. While the adepes, libma, and nignid are not mentioned words because the meaning is not clear, in other words, they are meaningless.

Word class of parts of speech, in most of the languages in the world including Indonesian, is traditionally divided into ten parts of speech, namely: noun, verb, adjective, pronoun, adverb, numeral, conjunction, article, interjection, and preposition. It can be concluded that word is the smallest unit of a language that is composed of letters/morphemes of which its meaning is clear, and it has a role in a sentence. The functions of words are divided into 10 , and it is known as the parts of speech or word classes.

From the translation of the novel Windmills of the Gods to Kincir Angin Para Dewa, the researcher found the datum as follow:

SL : That's what I mean.

TL : Itulah yang saya maksud.

In the data of this complex sentence 'That's what I mean' consists of an independent clause 'that's (what I mean) it' and a dependent clause 'what I mean' functioning as an object of the copula 'is'. The English dependent clause is translated into an Indonesian dependent clause yang saya maksud while the English independent clause is translated into Indonesian word itulah. Thus, it means that the shift occurs from a clause into a word.

\section{Shift from clause into phrase}

According to Finoza (2006, 89), phrase is a group of words without a predicate and have not completely formed a clause or sentence yet. While
Chaer $(2006,301)$ states that phrase is a combination of two words (or more) as a unit and being an element or function (as a subject, predicate, object, or complement) in a sentence construction.

These two definitions mean that a phrase is a group of words which does not have a subject and a predicate. A phrase is a group of two words or more which stand together and become one of the language elements or language function (subject, predicate, object or complement). This word group has a clear meaning because of its word arrangement. For example, the words langit batik biru baju is not a phrase although it consists of a group of the word because of the meaning is not clear. However, if the arrangement is changed into baju batik biru langit of which is has a clear meaning, it is said to be a phrase. Based on the function, there are four kinds of phrases. They are noun phrases, verb phrases, adjective phrases, and adverbial/ prepositional phrases. It can be concluded that a phrase is a group of words which does not have a subject and a predicate which stands together with a clear meaning and it can have the position of a subject, a predicate, an object or a complement.

From the translation of the novel, the writer found a datum as follow:

SL : Mary drove toward the town of Manhattan where the university was located sixteen miles away.

TL : Mary menuju kota Manhattan, ke kampus, kira-kira $16 \mathrm{mil}$ jauhnya.

The datum of this complex sentence 'Mary drove towards the town of Manhattan where the university was located sixteen miles away' consists of an independent clause 'Mary drove towards the town of Manhattan sixteen miles away' and a dependent clause 'where the university was located'. The dependent clause is translated into a phrase ke kampus. Thus, the shift occurs from a clause into a phrase. 


\section{Shift of Category}

This type of shift covers four different system of language transitions found in the novels.

\section{Shift from noun clause into clause}

A clause is a syntax level which is higher than a phrase but lower than a sentence. There are many theories concerning Indonesian clause, but only two will be quoted because they are the most relevant to this research. Ramlan (1987, 89) states that clause can be described as a grammatical unit which consists of, at least, a subject and a predicate, no matter it is completed by an object and/or complement or not. Thus, the basic elements of a clause is subject and predicate. In other words, the other elements (object and complement) may not present in a sentence. while Chaer $(2003,231)$ mentions that clause is a syntactic unit in the form or a word order constructed predicatively. It means that in the construction there are components in the forms of words or phrases which function as a predicate and the others as the subject, object, and complement. Beside predicate, another function which is obligatory in this construction is the subject since the others are optional.

Based on the two theories, it is clear that a clause is a language unit of which the subject and the predicate must be necessary constructed while the other elements are not. Compare these two constructions: kamar mandi (bath room) and adik mandi (my younger sister is taking a bath). Phrase kamar mandi is not a clause because there is no predicative element while adik mandi is a clause because adik has a function as an object and mandi has a function as a predicate. Clause construction which has subject and predicate has the chance to become a sentence, only if it has final intonations.

Based on its structure, there are two kinds of the clause: independent clause and bound clause (Chaer 2003, 235).
The independent clause has complete elements; at least it has a subject and a predicate and has the chance to become a sentence. While the bound clause does not have a complete structure. It has only a subject or an object or only a complement. It does not have the chance to become a sentence. For example, construction tadi pagi which is an answer to a question Kapan adik membaca komik? The bound clause can be recognized by subordinator in the initial position of the clause. For example, bound clause ketika kami sedangbelajar in sentence Dia pingsan ketika kami sedang belajar. A bound clause which is begun with a subordinator is commonly known as a sub-clause. A sub-clause cannot stand alone in a sentence that is why it must be attached to the main clause.The shift from clause into clause is subcategorizedinto the shift from one clause into another type of clause. The researcher found the datum as follow:

SL : I'm happy that I was in the right place at the right time.

\section{TL : Saya gembira karena berada di tempat yang tepat pada saat yang tepat.}

The datum of this complex sentence, 'I'm happy that I was in the right place at the right time' consists of an independent clause 'I'm happy and a dependent clause that I was in the right place at the right time'. The dependent clause shows a statement and therefore, in English grammar, it is said to belong to a noun clause with a conjunction 'that' showing statement. While the translation of the English complex sentence is Saya gembira karena berada di tempat yang tepat pada saat yang tepat. The English dependent clause is translated into Indonesian dependent clause karena berada di tempat yang tepat pada saat yang tepat. Because subordinator karena, this dependent clause is said to belong to an adverbial clause showing reason. There is a shift from a noun clause into an 
adverbial clause; in other words, this shift is also known as unit or rank shift.

\section{Shift from active into passive clause}

The datum of this complex sentence 'if it fails, I'm going to cut the knees' consists of an independent clause 'I'm going to cut the knees' and a dependent clause 'If it fails'. In English grammar, the independent clause is said to have an active form while its translation is in the form of passive. There is a shift from active into passive clause.

SL : If it fails, I'm going to cut the knees.

TL : Bila ini gagal, lututku akan serasa dipenggal.

\section{Shift from passive into active clause}

The datum of the complex sentence, 'I felt it only fair that you should be informed about this' consists of an independent clause ' $I$ felt it only fair' and a dependent clause that you should be informed'. In English grammar, such a dependent clause is said to be in passive form, but its translation is said to be in active form. There is a shift from passive to the active clause.

SL : I felt it only fair that you should be informed about this.

TL : Saya merasa bahwa lebih baik saya memberitahu Anda tentang hal ini.

Shift of position of independent and dependent clause

A complex sentence contains one independent clause and one or more dependent clauses (Oshima and Hague, 1999, 160). In a complex sentence, one idea is generally greater than the other one. The more important idea is placed in the independent clause, and the less important idea is placed in the dependent clause. There are three kinds of the dependent clause: adverbial clause, adjective clause, and noun clause.

The first is an adverbial clause a dependent clause beginning with an adverbial subordinator, for example, 'Although he had had ample opportunity to cheat on his wife, he had never given another woman a thought'. The complex sentence has an adverbial clause 'although he had had ample opportunity to cheat on his wife and the main clause he had never given another woman a thought'. Two possible positions for an adverbial clause is before or after the independent clause. If it comes before the independent clause, it is followed by a comma, like the previous example. If it comes after the independent clause, no comma is used, as the following example, 'he would never forget the morning when his colonel had called him into his office'. The researcher found a datum as follow:

SL : A pilot run for my whole program, if you will.

TL : Bila kau mau, jadilah pilot yang mengemudikan seluruh program$k u$.

In the datum, the complex sentence 'A pilot run for my whole program, if you will' consists of an independent clause 'A pilot run for my whole program' and a dependent clause 'if you will'. The position of the independent clause is before the dependent clause. While in the translation, the position of the independent clause is after the dependent clause. There is a shift in the independent-dependent clause position.

Shift from adverbial clause into adverbial clause (with a different kind of subordinator)

Joining the independent and dependent clause in an adverbial clause, a subordinator is needed. A subordinator plays an important role to show its function, namely, to show time, place, reason. Frank (1972, 19-20) states that subordinators that are used to show time are when, whenever, while, as soon as, after, since, before, as, and until. Subordinators that are used to show place are where, everywhere, wherever. Subordinators that are used to show reason are because, since, as, now, that, in as much as. Subordinators 
that are used to show condition are if and unless. Subordinators that are used to show contrast are although, though, eventhough, while, and whereas. Subordinators that are used to show purpose are in order that, and so that. Subordinators that are used to show result are: as + adjective + that, so + noun/adjective + that. Subordinators that are used to show manner are as if and as though.

The researcher found a datum as follow:

\section{SL : Do you still love now that I'm an older woman?}

\section{TL : Apakah kau tetap mencintaiku kini, setelah aku menjadi wanita yang semakin tua?}

The analysis of the sentences above is that the complex sentence 'Do you still love me now that I'm an older woman?' consists of an independent clause 'Do you still love me?' and a dependent clause 'now that I'm an older woman'. This complex sentence is translated into Apakah kau tetap mencintaiku kini, setelah aku menjadi wanita yang semakin tua. Both the English complex sentence and its translation belong to an adverbial clause. However, due to the presence of subordinator 'now that', it shows that the English adverbial clause is indicating a reason, while in its translation, the subordinator indicates that the adverbial clause is showing time with subordinator setelah. Although the type of the clause remains the same, the kind of the subordinator changes. It means that there is a shift from adverbial clause into adverbial clause with a different kind of subordinator.

\section{Shift from clause into sentence}

A sentence is a meaningful language unit in language study. It is because by using a sentence a teacher or someone can be able to express his or her thought clearly and completely whether it is written or spoken (Finoza 2006,
125). Complete here means that some elements should be available in a sentence, namely, a subject (must be available), a predicate (must be available), an object and a complement, like in the following example: Adik membaca buku di kamar. Adik is the subject of the sentence, and a verb membaca follows it as its predicate, buku is the object and di kamar as its complement. What are the differences between a sentence and a clause? Some people find difficulties in determining whether it is a sentence or a clause. Since a sentence expresses a thought clearly, there should be a final intonation in a sentence. There are three intonations which give features to a sentence that differ it from a clause. The first is the declarative intonation, which is in a written language, is symbolized by a period (.). The second is an interrogative intonation, which is in a written language, is symbolized by a question mark (?). Moreover, the last is exclamation intonation, which is in a written language, is symbolized by an exclamation mark (!).

A sentence is a minimal language unit, whether spoken or written which expresses a complete thought. In a spoken language, a sentence is uttered by rising and falling intonation, and when the ideais completely uttered, it is ended by a final intonation. While in a written language, when the thoughts entirely were written, a sentence is ended by putting punctuation marks, like aperiod (.), question mark (?), or an exclamation mark (!). In addition to those, within the sentence, other punctuation marks can also be available, like acomma (,), colon (:), semicolon (;), dash (-) and space. Other punctuation marks, besides period, question mark, and exclamation mark are in line with the rising and falling intonation, while period, question mark and exclamation mark are in line with the final intonation in a sentence. A sentence is a basic unit of discourse. It means that a discourse will 
be constructed if there are two or more than two sentences in a suitable arrangement and is based on the rules of discourse (Kamus Besar Bahasa Indonesia 2016).

In this research, the definitions of a sentence are described as follows: A sentence is a part of utterance which has a minimum structure of a subject $(\mathrm{S})$ and a predicate $(\mathrm{P})$ whose intonation shows that it has been completed with meaning (Finoza 2006, 125). While the following definition is stated by Chaer (2006, 327): sentence is a language unit containing a sort of complete 'thought' or 'idea'.

The researcher found a datum as follow:

\section{SL : She found that she was crying. \\ TL : Ia menangis.}

The analysis of the sentences above is that the complex sentence 'She found that she was crying' consists of an independent clause 'she found it (that she was crying') and a dependent clause which has functioned as an object of the verb 'found that she was crying'. The dependent clause is translated into a sentence ia menangis. Thus, it means that the shift occurs from a clause into a sentence.

\section{Conclusions}

The result of the data analysis revealed that there are shifts on the translation of English clauses in complex sentences into Indonesia. The shift occurs from a clause into a word, from a clause into a phrase, from a clause into a clause and a clause into a sentence. Among ten bestrepresentative findings of translation shifts occurred in theoriginal text of the English novel Windmills of the Gods and its Indonesian translation Kincir Angin Para Dewa there are two kinds of level shifts: clause-to-word shift and clause-to-phrase shift. In addition to these, there are six types of category shifts, such as noun-clause-to-adverbial shift, independent-clause-to-dependentclause shift, adverbial-clause-toadverbial-clause shift by replacing subordinator, and clause-to-sentence shift. These four are also called as unit or rank shift. The other shifts include active-to-passive shift and passive-toactive shift. These are the structure shifts.

A translator may come across many difficulties in finding the equivalence of the source language in the target language due to the differences structure of both languages. Although a translator has to retain the style and the form of the source language, he or she has to adjust his or her translation to get the naturalness in the target language, and shift may become something that they have to face whether at the level of word, phrase, clause or sentence. Further research in the translation of clauses from English into Indonesian or vice versa is vastly recommended because of the differences in the structure of both languages.

\section{REFERENCES}

Alwi, H. et. al. 2003. Tata Bahasa Baku Bahasa Indonesia. Jakarta: Balai Pustaka

Kamus Besar Bahasa Indonesia. 2016. (Edisi ke-5). Jakarta: Balai Pustaka

Badudu, JS 1992. Cakrawala Bahasa Indonesia II. Jakarta: PT. Gramedia Pustaka Utama

Bloomfield, L. 2017.Language. Delhi: Narendra Prakash Jair, 1996. $<$ https://books. google.com/books?id= iqg7hUcRzPIC\&printsec=frontcover\&so urce=gbs_book_other_versions\#v=onepa ge\&q\&f=false> Accessed January 21, 2017

Burns, RB. 2000. Introduction to Research Methods (4th Edition). London: Sage Publications

Catford, JC. 1974. A Linguistic Theory of Translation. London: Oxford University Press

Chaer, A. 2003. Linguistik Umum. Jakarta: PT Rineka Cipta 
Chaer, A. 2006. Tata Bahasa Praktis Bahasa Indonesia (Edisi ke-2). Jakarta: Rineka Cipta

Finoza, L. 2006. Komposisi Bahasa Indonesia. Jakarta: Diksi Insan Mulia

Frank, M. 1972. Modern English: A Practical Reference Guidance. New York: Prentice Hall Inc.

Gentzler, E. 1993. Contemporary Translation Theory. New York: Routledge Inc.

Halliday, MAK. 1994. Introduction to Functional Grammar. London: Arnold

Hellystia, D. 2013. The Equivalence and Shift of English Clauses Translation from Indonesian. <http://library. gunadarma.ac.id/repository/view/3752 729/the-equivalence-and-shift-in-thetranslation-of-english-clauses-from-indo nesian.html/> Accessed January 21, 2017

Hornby, AS. 1989. Oxford Advanced Learner's Dictionary. Oxford: Oxford University Press

Kridalaksana, H. 2009. Kamus Linguistik. Jakarta: PT. Gramedia
Larson, ML. 1998. Meaning-Based Translation: A Guide to Cross-Language Equivalence (2 ${ }^{\text {nd }}$ Edition). USA: University Press of America Inc.

Munday, J. 2000. Introducing Translation Studies: Theories and Applications (1 ${ }^{\text {st }}$ Edition). New York: Routledge,

Newmark, P. 1988. A Text Book on Translation. England: Prentice Hall International UK Ltd.

Nunan, D. 1992. Research Methods in Language. Cambridge: Cambridge University Press

Oshima, A \& A. Hogue. 1999. Writing Academic English (3rd Edition). London: Longman

Ramlan, M. 1987. Sintaksis. Yogyakarta: CV Karyono

Schmidt, R \& JC Richards. 2010. Longman Dictionary of Language Teaching and Applied Linguistics (4th Edition). Harlow: Longman

Sheldon, S. 1987. Windmills of the Gods. USA: Warner Books

Sheldon, S. 2003. Kincir Angin Para Dewa. Jakarta: Gramedia Pustaka Utama 